[Chem. Pharm. Bull.

32(12)4979--4985(1984)]

\title{
The Immunological Crossreaction between Human $\alpha$-Fetoprotein and Serum Albumin and Its Relation with the Binding Ability
}

\author{
Kazuyuki Hirano, * Yoshihito Watanabe, Tetsuo Adachi, \\ Yoshimasa Ito and MAMORU SugIURA
}

Gifu Pharmaceutical University, 6-1, Mitahora-higashi 5-chome, Gifu 502, Japan

(Received March 19, 1984)

\begin{abstract}
The crossreactivity between human $\alpha$-fetoprotein and serum albumin in their unfolded forms was investigated by immunological methods. On enzyme immunoassay and immunostaining, reduced and carboxyamidomethylated human $\alpha$-fetoprotein and serum albumin crossreacted with antibodies to their unfolded forms and weakly reacted with those to their native forms. Peptide fragments of human $\alpha$-fetoprotein and serum albumin cleaved only by cyanogen bromide were nonreactive with antibodies to their native forms and with those to their unfolded forms. However, after reduction and carboxyamidomethylation, the peptide fragments prepared were mostly crossreactive with antibodies of their unfolded forms, but not with those of their native forms. While the native forms of human $\alpha$-fetoprotein and serum albumin and their peptide fragments obtained by cyanogen bromide cleavage retained binding abilities with bilirubin and anilinonaphthalene sulfonate, the unfolded forms had no binding abilities. These findings suggest that the binding abilities, proposed to be related to the biological functions of human $\alpha$-fetoprotein and serum albumin, are mainly attributable to their conformational character rather than to their primary sequences.
\end{abstract}

Keywords-human $\alpha$-fetoprotein; human serum albumin; immunological crossreactivity; enzyme immunoassay; immunostaining; binding ability

$\alpha$-Fetoprotein(AFP) is a glycoprotein which comprises most of the mammalian fetal plasma proteins in the first trimester. ${ }^{1)}$ It also reappears in sera of patients with hepatocellular carcinoma, teratocarcinoma, ${ }^{2)}$ yolk sac tumor and developmental disorders ${ }^{3)}$ and is considered to be a tumor marker. The proposed functions of AFP include the binding of various substances, such as copper, ${ }^{4)}$ fatty acids $^{5)}$ and various dyes, ${ }^{6)}$ and immunoregulatory effects. $^{7,8)}$ We have recently reported ${ }^{9)}$ the interrelationship between AFP and human serum albumin (HSA) as carrier proteins, supporting the view that AFP plays an important role in the fetal body. However, the biological role of AFP remains to be fully elucidated.

AFP shares many similarities with HSA, including sequence homology, ${ }^{10,11)} \mathrm{immu}$ nological reactivity ${ }^{12-14)}$ and physiological properties. ${ }^{8,15)}$ In 1976, Ruoslahti and Engvall ${ }^{12)}$ reported that AFP and HSA showed immunological crossreaction when unfolded by the reduction of disulfide bonds followed by carboxyamidomethylation, while they did not crossreact in their native forms. The crossreactivity can be regarded as indicative of similarity in the primary structure. Recently Morinaga et $a l .{ }^{11)}$ reported the amino acid sequence of human AFP based on the sequence of cloned deoxyribonucleic acid (DNA) complementary to human AFP messenger ribonucleic acid (mRNA) and found a 39\% conservation of primary structure in comparison with HSA. These results confirmed that AFP is very similar to HSA at the primary structure level and supported the hypothesis that AFP and HSA had a common ancestral gene.

HSA is known to be the most important carrier protein, and it binds various ligands such as bilirubin, ${ }^{16)}$ fatty acids, ${ }^{17)}$ drugs, ${ }^{18)}$ and other small molecules. Since the primary structure of 
HSA was reported by Meloun et al. ${ }^{19)}$ in 1975, the binding sites within the HSA molecule have been investigated in detail. ${ }^{20)}$ However, because of the difficulty in obtaining pure AFP from human tissues, little is known about the location of ligand binding sites in AFP. ${ }^{5)}$

In this work, we have investigated the interrelationship between AFP and HSA in their native and unfolded forms by means of immunological methods. Then, to clarify the immunological relationship between AFP and HSA in detail, peptide fragments were prepared and reinvestigated by the same methods. Furthermore, the binding ability, which is related to the biological function of HSA and probably also that of AFP, was examined at the peptide level, and the correlation between the homology and the binding ability is discussed.

\section{Materials and Methods}

Human AFP was purified from human cord serum with an immunoadsorbent column as described in the previous paper. ${ }^{21)}$ Polystyrene beads $(6.5 \mathrm{~mm}$ in diameter $)$ were purchased from Ichico Co., horseradish peroxidase (Type VI) was from Sigma Co. Sephadex G-25, Sephadex G-150 and Protein A-Sepharose CL-4B were from Pharmacia Fine Chemicals, and HSA and horseradish peroxidase-labelled goat anti-rabbit $\gamma$-globulin were from Miles Laboratories. Nitrocellulose membrane was from Bio-Rad Laboratories. Anilinonaphthalene sulfonate was from Tokyo Kasei Co. Other reagents were of analytical reagent grade.

Reduction and Alkylation-AFP and HSA were reduced and alkylated according to the method of Crestfield $e t$ al. ${ }^{22)}$ The samples were dissolved at a concentration of about $10 \mathrm{mg} / \mathrm{ml}$ in $0.1 \mathrm{M} \mathrm{Tris-HCl}$ buffer $(\mathrm{pH} 8.2$ ) containing $8 \mathrm{M}$ urea. After deaeration with $\mathrm{N}_{2}$, dithiothreitol was added to a final concentration of $10 \mathrm{~mm}$. After $3 \mathrm{~h}$ at room temperature under $\mathrm{N}_{2}$, the reaction mixture was cooled on ice, and iodoacetamide was added to give the final concentration of $20 \mathrm{~mm}$. After another $15 \mathrm{~min}$, the sample was dialyzed against $20 \mathrm{~mm}$ phosphate buffer (pH 7.4) containing $0.15 \mathrm{M} \mathrm{NaCl}, 0.02 \%$ sodium azide, $0.1 \%$ Triton $\mathrm{X}-100$ and $2 \mathrm{M}$ urea.

Preparation of Peptide Fragments - The preparation of cyanogen bromide peptide fragments of AFP and HSA was done according to the method of McMenamy et al ${ }^{23)}$ with a minor modification. AFP $(0.2 \mathrm{mg})$ or HSA $(0.2 \mathrm{mg})$ was dissolved in $2 \mathrm{ml}$ of $80 \%$ formic acid containing $0.1 \mathrm{~g}$ of cyanogen bromide and stored at $4{ }^{\circ} \mathrm{C}$ for $20 \mathrm{~h}$. Further experiments were conducted at room temperature. The solution was applied to a Sephadex G-25 column $(2 \times 90 \mathrm{~cm})$ in $0.1 \%$ propionic acid and the peptide-containing fractions were collected and lyophilized. After being freeze-dried, the protein was dissolved in $1 \mathrm{ml}$ of $7 \mathrm{M}$ guanidine hydrochloride under $\mathrm{N}_{2}$, and $0.4 \mathrm{ml}$ of $7 \mathrm{M}$ guanidine hydrochloride containing $20 \mathrm{mg}$ of dithiothreitol was added. The $\mathrm{pH}$ was adjusted to 10.0 by the addition of $1 \mathrm{~N} \mathrm{NaOH}$ and the reaction was carried out under $\mathrm{N}_{2}$ at room temperature for $3 \mathrm{~h}$. The $\mathrm{pH}$ was adjusted to 8.5 by the addition of $1 \mathrm{~N} \mathrm{HCl}$ and then $0.16 \mathrm{~g}$ of iodoacetamide dissolved in $0.6 \mathrm{ml}$ of $7 \mathrm{M}$ guanidine hydrochloride was added to the solution. The reaction chamber was covered with aluminum foil and the mixture was held at $\mathrm{pH} 8.5$ under $\mathrm{N}_{2}$ for $1.5 \mathrm{~h}$. The $\mathrm{pH}$ was adjusted to 2.5 by the addition of $1 \mathrm{~N} \mathrm{HCl}$ and the solution was immediately applied to a Sephadex G-25 column $(2 \times 90 \mathrm{~cm})$ in $0.01 \mathrm{M}$ phosphoric acid $(\mathrm{pH} 2.0)$. The peptide-containing fractions were collected and lyophilized.

Antiserum — Rabbit anti-AFP antiserum was prepared as described previously. ${ }^{21)}$ In a similar manner, we produced antisera to the reduced and carboxymethylated-AFP (RC-AFP) (1 mg per injection), HSA (5 mg per injection) and RC-HSA ( $5 \mathrm{mg}$ per injection) in rabbits. IgG fraction was obtained from each antiserum by ammonium sulfate fractionation, followed by passage through a DEAE-cellulose column then a Protein A-Sepharose CL-4B column.

Preparation of Antibody-Coated Polystyrene Beads_-Antibody was coated on polystyrene beads according to the method of Kato et al. ${ }^{24)}$ Polystyrene beads were immersed in a detergent (Scat 20X-PF) and then washed thoroughly with distilled water. The beads were incubated with antibody $(50 \mu \mathrm{g} / \mathrm{ml})$ dissolved in $0.25 \mathrm{M}$ sodium phosphate buffer ( $\mathrm{pH} 7.5$ ) at $37^{\circ} \mathrm{C}$ for $1 \mathrm{~h}$, and then allowed to stand at $4{ }^{\circ} \mathrm{C}$ overnight. The beads were washed several times with $10 \mathrm{~mm}$ sodium phosphate buffer $(\mathrm{pH} 7.0$ ) containing $0.1 \mathrm{M} \mathrm{NaCl}, 0.1 \%$ bovine serum albumin (BSA) and $0.01 \%$ thimerosal sodium (buffer A), then stored at $4{ }^{\circ} \mathrm{C}$ until use.

Preparation of Antibody Conjugated with Peroxidase-- Antibody conjugated with peroxidase was prepared according to the method of Avrameas and Guilbert. ${ }^{25)}$ Peroxidase $(20 \mathrm{mg}$ ) was dissolved in $0.15 \mathrm{ml}$ of $0.1 \mathrm{M}$ sodium phosphate buffer ( $\mathrm{pH} \mathrm{6.8)} \mathrm{containing} 1.25 \%$ glutaraldehyde. The solution was allowed to stand for $18 \mathrm{~h}$ at room temperature and then applied to a Sephadex G-25 column $(1.2 \times 90 \mathrm{~cm})$ equilibrated with $0.15 \mathrm{M} \mathrm{NaCl}$. The fractions $(4 \mathrm{ml})$ and $0.1 \mathrm{ml}$ of $1 \mathrm{M}$ carbonate buffer $(\mathrm{pH} \mathrm{9.5)}$ were added and mixed, then $5 \mathrm{mg}$ of the antibody was immediately added to the mixture. After standing for $24 \mathrm{~h}$ at $4{ }^{\circ} \mathrm{C}$, the reaction mixture was applied to a Sephadex G-200 column $(2.7 \times 90 \mathrm{~cm})$ equilibrated in phosphate-buffered saline. The peroxidase labelled antibody fractions were collected and mixed with an equal volume of glycerin containing $0.01 \%$ thimerosal sodium. The mixture was stored at $4{ }^{\circ} \mathrm{C}$ until use. Before use, it was diluted 20 -fold with buffer A containing $0.1 \%$ Triton X-405 (buffer A-T).

Enzyme Immunoassay_ An antibody-coated polystyrene bead was incubated with $0.2 \mathrm{ml}$ of the sample diluted in buffer $\mathrm{A}-\mathrm{T}$ at $37^{\circ} \mathrm{C}$ for $3 \mathrm{~h}$ with shaking and then the bead was washed three times with $2 \mathrm{ml}$ of $10 \mathrm{~mm}$ sodium 
phosphate buffer ( $\mathrm{pH} 7.4$ ) containing $0.15 \mathrm{M} \mathrm{NaCl}$ and $0.05 \%$ Tween 20 (buffer $\mathrm{R}$ ). The bead was incubated with $0.2 \mathrm{ml}$ of the antibody solution conjugated with peroxidase at room temperature overnight, and washed three times with $2 \mathrm{ml}$ of buffer $\mathrm{R}$. The bead was transferred to another tube and the activity of peroxidase bound to the polystyrene bead was assayed. Each bead was incubated with $0.2 \mathrm{ml}$ of $0.1 \mathrm{M}$ phosphate-citrate buffer (pH 6.5 ) containing $0.3 \%$ o-phenylenediamine and $0.02 \% \mathrm{H}_{2} \mathrm{O}_{2}$ at $37{ }^{\circ} \mathrm{C}$ for $15 \mathrm{~min}$. The enzyme reaction was terminated by the addition of $2 \mathrm{ml}$ of $1 \mathrm{~N} \mathrm{HCl}$. The absorbance at $492 \mathrm{~nm}$ of the resulting solution was measured.

Immunoperoxidase Staining of Protein Transferred from Sodium Dodecyl Sulfate (SDS) Polyacrylamide Gel to Nitrocellulose Filter-Proteins were separated on polyacrylamide gels in the presence of SDS and 2-mercaptoethanol, ${ }^{26)}$ and the resulting protein bands were transferred to nitrocellulose filters according to Bowen et $a l^{27)}$ After thorough washing of the filters with $20 \mathrm{~mm}$ potassium phosphate buffer $(\mathrm{pH} 7.4)$ containing $0.15 \mathrm{M} \mathrm{NaCl}$ and $0.05 \%$ Tween 20 (T-PBS), the filters were incubated with $20 \mathrm{~mm}$ potassium phosphate buffer (pH 7.4) containing $0.15 \mathrm{M} \mathrm{NaCl}$ and $3 \% \mathrm{BSA}$ (BSA-PBS) at $37{ }^{\circ} \mathrm{C}$ for at least $4 \mathrm{~h}$ for the purpose of nonspecific adsorption blocking. After thorough washing of the filters with T-PBS, antiserum solution diluted to $100 \mu \mathrm{g} / \mathrm{ml}$ in BSA-PBS was added. The filters were incubated at $37^{\circ} \mathrm{C}$ for $3 \mathrm{~h}$. After thorough washing with T-PBS, the filters were further incubated with horseradish peroxidase-labelled goat anti-rabbit $\gamma$-globulin in BSA-PBS at $37^{\circ} \mathrm{C}$ for $4 \mathrm{~h}$. After another washing of the filters with T-PBS, the protein band that had bound to the nitrocellulose filter was visualized by incubation in substrate solution containing $0.25 \mathrm{mg} / \mathrm{ml}$ benzidine and $0.25 \% \mathrm{H}_{2} \mathrm{O}_{2}$ in $50 \mathrm{~mm}$ Tris- $\mathrm{HCl}$ buffer $(\mathrm{pH} 7.2)$ at $37^{\circ} \mathrm{C}$ with protection from light.

Determination of Bilirubin Binding _ - The binding of bilirubin was determined by using a spectrophotometer or a spectrofluorometer according to the previous paper. ${ }^{9}$ )

Determination of ANS Binding ---The binding of ANS to the hydrophobic binding sites was measured by using a spectrofluorometer. Excitation was performed at $370 \mathrm{~nm}$ and emission was determined by scanning from 400 to $500 \mathrm{~nm}$. The slit width was $10 \mathrm{~nm}$ for excitation and for emission. All measurements were made at room temperature and in $20 \mathrm{~mm}$ potassium phosphate buffer ( $\mathrm{pH} 7.4)$.

\section{Results}

\section{Immunological Crossreaction between AFP and HSA in Their Native Forms and Unfolded Forms}

AFP and HSA did not show immunological crossreaction in their native forms. However, following reduction and carboxyamidomethylation, the unfolded forms of AFP and HSA crossreacted with antibodies of their RC-derivatives on enzyme immunoassay, as shown in Fig. 1. The reactivity of RC-HSA with anti-RC-AFP antibody appeared to be stronger than that of RC-AFP with anti-RC-HSA antibody. Unfolded forms of AFP and HSA also seemed to react weakly with antibodies of their native proteins (data not shown),
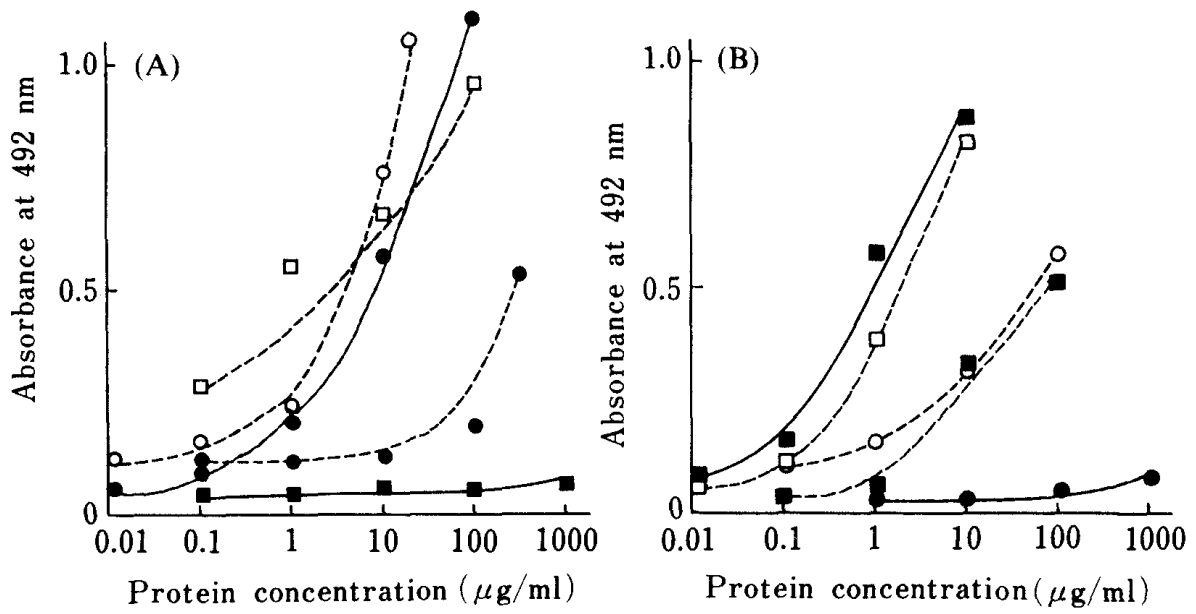

Fig. 1. Crossreaction between $\alpha$-Fetoprotein and Serum Albumin Investigated by Enzyme Immunoassay

The crossreactions among HSA ( $\square)$, RC-HSA $(\square)$, AFP $(\bullet)$ and RC-AFP (O) were investigated using (A) anti-AFP ( $-{ }_{-}$, anti-RC-AFP $(-\cdots-)$, (B) anti-HSA $(-)$ and anti-RC-HSA (-....) antibodies. 
(A)

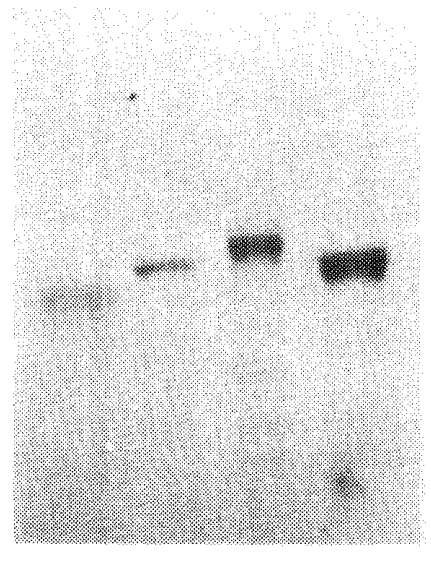

(B)

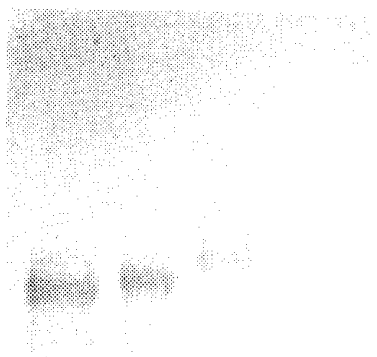

(C)

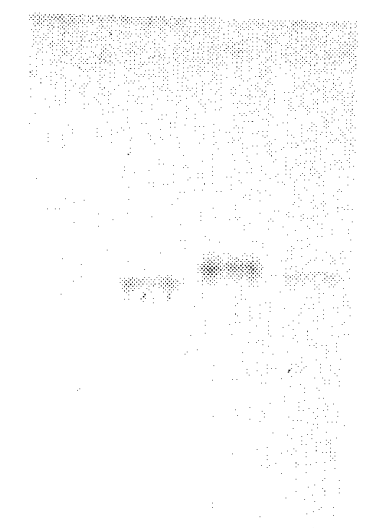

$\begin{array}{llll}1 & 2 & 3 & 4\end{array}$

Fig. 2. Immunoperoxidase Staining of Proteins Transferred from SDS Polyacrylamide Gels to Nitrocellulose Filters

(A) shows the 7.5\% gel stained for protein with Coomassie Brilliant Blue R-250. (B) and (C) are the corresponding filters stained by the immunoperoxidase method with anti-RCHSA (B) and anti-RC-AFP (C) antibodies.

1, HSA; 2, RC-HSA; 3, RC-AFP; 4, AFP.

(A)

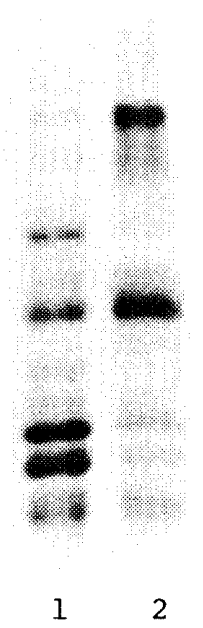

(B)

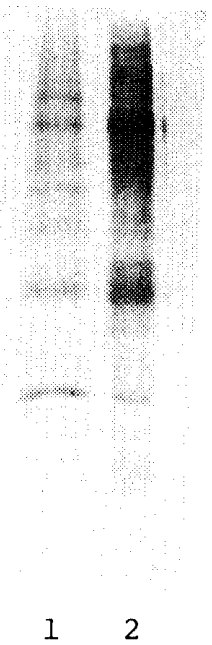

(C)

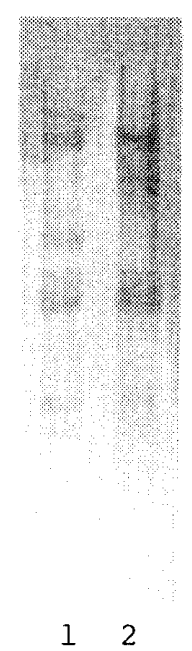

Fig. 3. Immunoperoxidase Staining of Peptide Fragments Transferred from SDS Polyacrylamide Gels to Nitrocellulose Filters

(A) shows the $15 \%$ gel stained for unfolded forms of the cyanogen bromide peptide fragments with Coomassie Brilliant Blue R-250. (B) and (C) are the corresponding filters stained by the immunoperoxidase method with anti-RC-HSA (B) and anti-RC-AFP (C) antibodies.

1, RC-HSA; 2, RC-AFP.

and AFP and HSA reacted with antibodies of their RC-derivatives.

In the immunostaining investigation, corresponding to the protein bands stained with Coomassie Brilliant Blue R-250 in Fig. 2(A), unfolded forms of AFP and HSA crossreacted with anti-RC-HSA antibody (Fig. 2(B)) and anti-RC-AFP antibody (Fig. 2(C)). They also appeared to react weakly with antibodies to their native protein (data not shown). Native forms of AFP and HSA appeared to react weakly with antibodies to the corresponding RCderivatives in Figs. 2(B) and 2(C). 
TABLE 1. Association Constants of $\alpha$-Fetoprotein and Serum Albumin with Bilirubin and ANS

\begin{tabular}{lccccc}
\hline & \multicolumn{2}{c}{ AFP $\left(\mathrm{M}^{-1}\right)$} & & \multicolumn{2}{c}{$\operatorname{HSA}\left(\mathrm{M}^{-1}\right)$} \\
\cline { 2 - 3 } \cline { 5 - 6 } & Native forms & BrCN-treated & & Native forms & BrCN-treated \\
\hline Bilirubin & $7.8 \times 10^{6}$ & $2.9 \times 10^{8}$ & & $3.1 \times 10^{7}$ & $5.5 \times 10^{8}$ \\
ANS & $4.1 \times 10^{7}$ & $7.9 \times 10^{7}$ & & $7.7 \times 10^{7}$ & $2.7 \times 10^{7}$ \\
\hline
\end{tabular}

The association constants were calculated from Scatchard plots. ANS; Anilinonaphthalene sulfonate.

\section{Immunological Crossreaction of the Peptide Fragments Cleaved by Cyanogen Bromide}

The peptide fragments obtained by cyanogen bromide cleavage were run on $15 \%$ polyacrylamide gel, but the bands on nitrocellulose filters were not stained with anti-AFP antibody, anti-RC-AFP antibody, anti-RC-HSA antibody or anti-HSA antibody. The peptide fragments were subjected to reduction and carboxyamidomethylation, and run on $15 \%$ polyacrylamide gel. Corresponding to the bands stained with Coomassie Brilliant Blue R-250 in Fig. 3(A), almost all the peptide fragments prepared from AFP and HSA were stained with anti-RC-HSA antibody (Fig. 3(B)) and anti-RC-AFP antibody (Fig. 3(C)), and appeared to crossreact. However, they did not react with antibodies to their native proteins (data not shown).

\section{Binding Abilities to Bilirubin and ANS}

Both AFP and HSA in their native forms bound with bilirubin and ANS as shown in Table I, but RC-AFP and RC-HSA did not bind with bilirubin or ANS, (a reagent for detecting hydrophobic anion binding sites). However, peptide fragments of AFP and HSA formed by cyanogen bromide cleavage bound bilirubin and ANS with higher association constants than the native proteins.

\section{Discussion}

AFP is the predominant protein in the first trimester and then decreases in the third trimester, whereas HSA appears in the second trimester and reaches the adult level at birth. AFP is very similar to HSA in many respects. ${ }^{8,10-14)}$ It had been proposed that AFP functions as a carrier protein in the fetal body.

In the enzyme immunoassay and immunostaining investigation, the RC-derivatives of AFP and HSA appeared to crossreact. This result is consistent with the report of Ruoslahti and Engvall. ${ }^{12)}$ Furthermore, since AFP shows a $39 \%$ homology of the primary structure with HSA, ${ }^{11)}$ the immunological crossreactivity was considered to be a consequence of unfolding of the native protein (i.e., related to the primary structure), whereas antibody response against the native protein was considered to reflect conformational rather than sequential determinants. Only trace amounts of AFP and HSA seemed to react with antibodies of their RC-derivatives, indicating that the native forms and unfolded forms are immunologically distinct. The mobility of RC-protein on SDS polyacrylamide gel electrophoresis was slower than that of the native protein. This difference is consistent with the full unfolding of the native protein to the primary structure.

Further, to confirm the immunological crossreaction between AFP and HSA, peptide fragments were prepared to investigate which peptide fragments possessed the antigenic determinants. Cyanogen bromide was employed since it specifically cleaves at the CO site of methionine residue. HSA has $6 \mathrm{Met}$, among which $\mathrm{Met}^{123}$ and $\mathrm{Met}^{298}$ are cleaved to give 3 
fragments $(1-123,124-298,299-585) \cdot{ }^{23)}$ AFP has 8 Met, but only Met $^{266}$ is cleaved to give 2 fragments, according to Morinaga et al. ${ }^{11}$

The peptide fragments of AFP and HSA prepared by cyanogen bromide cleavage did not react with antibodies to their native proteins or with those to their $\mathrm{RC}$-derivatives. The peptide fragments were therefore reduced and carboxyamidomethylated. Almost all the peptide fragments thus obtained crossreacted with antibodies to their RC-derivatives. This shows similarity at the peptide fragment level and further confirms the homology of primary amino acid sequence between AFP and HSA. However, all of these peptide fragments of AFP and HSA failed to react with antibodies against their native proteins.

The numbers of peptide fragments obtained only by cyanogen bromide cleavage were 3 for HSA and 2 for AFP. These peptide fragments were expected to have molecular conformational structure, though the antigenic determinants of the native HSA and AFP would be disrupted or lost. Indeed, these peptide fragments were immunologically distinct from the native proteins and from the unfolded proteins. However, after reduction and carboxyamidomethylation, the numbers of peptide fragments were 7 for HSA and 9 for AFP. These were unfolded, and crossreacted with antibodies to the RC-derivatives.

AFP and HSA are shown to be very similar and homologous in terms of cyanogen bromide peptide fragments ${ }^{10)}$ and the whole sequence. ${ }^{11)}$ In this paper, it is shown that they are immunologically distinguishable even at the peptide fragment level when unfolded to the primary structure, though the lack of reactivity of these fragments with antibodies to their native proteins suggests that the constituents of the antigenic determinants were rather different.

Furthermore, AFP and HSA were examined to clarify the relationship between amino acid sequence homology and binding ability. AFP and HSA were reported to have similar three-domain structures ${ }^{11,28)}$ and they differed slightly in ability to bind ligands. ${ }^{5,9,29)}$ As described previously, ${ }^{9)}$ native AFP and HSA bind bilirubin. The ability to bind ligands, such as bilirubin, fatty acids, drugs and dyes, is believed to depend on hydrophobic anion binding sites on the native protein. Therefore, ANS, a reagent for the detection of hydrophobic anion binding sites, was also employed. We found that both AFP and HSA bound ANS.

The binding abilities of the mixture of cyanogen bromide-cleaved peptide fragments with bilirubin and ANS were investigated and the association constants were found to be higher than those of the native proteins. The increase of the association constants is probably attributable to exposure of the binding sites. However, the RC-derivatives of AFP and HSA had no binding ability with bilirubin as determined by spectral and fluorescence measurements.

AFP and HSA were similar in that the peptide fragments formed by cyanogen bromide retained binding ability with bilirubin and ANS. However, unfolding of the native proteins results in loss of the binding abilities. Thus, it is suggested that the conformations of the proteins are required for the binding abilities. The binding sites of bilirubin within the HSA molecule were suggested to exist in domain $2 .^{20)}$ AFP lacks a double disulfide bridge in the second half of domain $2,{ }^{11)}$ so differences of binding abilities between AFP and HSA may be due to the differences in molecular conformations, especially in domain 2.

In conclusion, the proposed function of AFP as a carrier protein is consistent with the fact that both AFP and HSA have similar three domain structures. The significant point may be the conformational similarities between AFP and HSA rather than the sequence homology.

\section{References and Notes}

1) D. Gitlin and M. Boesman, J. Clin. Invest., 45, 1826 (1966). 
2) G. I. Abelev, Acta Unio. Int. Contra. Cancrum, 19, 80 (1963).

3) D. Collet-Cassart, C. G. M. Magnusson, J. G. Ratcliffe, C. L. Cambiaso and P. L. Masson, Clin. Chem., 27, 64 (1981).

4) Y. Aoyagi, T. Ikenaka and F. Ichida, Cancer Res., 38, 3483 (1978).

5) C. B. Berde, M. Nagai and H. F. Deutsch, J. Biol. Chem., 254, 12609 (1979).

6) Y. Endo, K. Kanai, S. Ino and T. Oda, "L'Alpha-Foetoproteine," ed. by R. Masseyeff, Inserm, Paris, 1974, pp. $47-55$.

7) R. A. Murgita and H. Wigzell, La Ricerca Clin. Lab., 9, 327 (1979).

8) E. P. Lester, J. B. Miller and S. Yachnin, Proc. Natl. Acad. Sci. U.S.A., 73, 4645 (1976).

9) K. Hirano, Y. Watanabe, T. Adachi and M. Sugiura, Chem. Pharm. Bull., 32, 708 (1984).

10) E. Ruoslahti and W. D. Terry, Nature (London), 260, 804 (1976).

11) T. Morinaga, M. Sakai, T. G. Wegmann and T. Tamaoki, Proc. Natl. Acad. Sci. U.S.A., 80, 4604 (1983).

12) E. Ruoslahti and E. Engvall, Proc. Natl. Acad. Sci. U.S.A., 73, 4641 (1976).

13) A. Pekkala-Flagan and E. Ruoslahti, J. Immunol., 128, 1163 (1982).

14) G. C. M. Selten, H. M. G. Princen, A. M. E. Selten-Versteegen, G. P. B. M. Mol-Backx and S. H. Yap, Biochim. Biophys. Acta, 699, 131 (1982).

15) H. Hirai, S. Nishi, H. Watabe and Y. Tsukada, Gann Monogr. Cancer Res., 14, 19 (1973).

16) J. Jacobsen, FEBS Lett., 5, 112 (1969).

17) A. A. Specton, J. Lipid Res., 16, 165 (1975).

18) U. Kragh-Hansen, Pharmacol. Rev., 33, 17 (1981).

19) B. Meloun, L. Moravek and V. Kostka, FEBS Lett., 58, 134 (1975).

20) K. J. Fehske, W. E. Muller and U. Wollert, Biochem. Pharmacol., 30, 687 (1981).

21) Y. Watanabe, T. Adachi, Y. Ito, K. Hirano and M. Sugiura, Chem. Pharm. Bull., 30, 3284 (1982).

22) A. M. Crestfield, S. Moore and W. H. Stein, J. Biol. Chem., 238, 622 (1963).

23) R. H. McMenamy, H. M. Dintzis and F. Watson, J. Biol. Chem., 246, 4744 (1971).

24) K. Kato, Y. Hamaguchi, S. Osawa, E. Ishikawa, K. Kobayashi and K. Katsunuma, J. Biochem. (Tokyo), 81, 1557 (1977).

25) S. Avrameas and B. Guilbert, Biochimie, 54, 837 (1972).

26) K. Weber and M. Osborn, J. Biol. Chem., 244, 4406 (1969).

27) B. Bowen, J. Steinberg, U. K. Laemmli and H. Weintraub, Nucleic Acids Res., 8, 1 (1980).

28) J. R. Brown, Fed. Proc., Fed. Am. Soc. Exp. Biol., 35, 2141 (1976).

29) C. B. Berde, B. S. Hudson, R. D. Simoni and L. A. Sklar, J. Biol. Chem., 254, 391 (1979). 